\title{
Editorial
}

\section{Phenotype としての心電図：左室肥大を例に}

心電学は心臟病学の基礎である。しかしその phenotype(表現形)である心電図の診断が，単なる パターン診断で終わってしまっているとしたらもっ たいない。より本質に迫るイマジネーションを働か せることはできないだろうか.

例えば，高血圧例ではしばしば “左室肥大”，と いう単純な心電図診断が下される。しかし，そもそ も肥大があるとなぜ左側胸部誘導の R 波高が大きく なるのか？胸部誘導は胸壁の上で単極記録をとって いるため, 肥大により心臟と胸郭との距離が近づけ ばそれも一因となる。また，左側胸部誘導の R 波は 心外膜面での電位記録を反映しているため, Purkinje線維が分布する心内膜側から心外膜側に向 かう貫壁性電流にとくに敏感である. その壁が厚く， したがって貫壁性の距離が長く, 伝導に時間がかか ればそれだけ高いR波を記録できることになる。さ らに, 肥大に伴って心筋の線維化や ${ }^{1)}$, gap junction の障害 ${ }^{2}$ といった病的 remodelingが進行すれば， R 波が高くなるだけでなく，その傾き(intrinsicoid deflection)の急峻さも失われ, QRS幅も拡がること になる．肥大心における伝導遅延は reentryのため の環境を形成し，突然死のリスクを高めることにつ ながる ${ }^{3)}$.

イメージを膨らませる対象はQRS 波だけではな い. 肥大が進むといわゆる strain patternが観察さ れる。心外膜側からの記録としてみれば，そこでの 再分極終末部が心内膜側のそれよりも遅いことを意 味している。原因として，(1)心外膜までの貫壁性伝 導に時間がかかり, 心外膜側の活動電位の開始が遅
東京都済生会中央病院循環器科 三田村秀雄

れた, (2)心内膜側の活動電位が短くなった, (3)心外 膜側の活動電位が長くなった，の三つの可能性が考 えられる，1番目の機序は，すでに述べた $\mathrm{R}$ 波の変 化に追随するものであるが, 心外膜側の脱分極が遅 れることでその部位の再分極はさらに遅れ, それが 心内膜側の再分極の終了後にまで延長すると, ST 終末部が下向きになるというものである．2番目の 機序は心内膜下虚血によって起こりうるが, それが 実際に関係しているかは明らかでない，確かに肥大 心では心内膜側の血流が健常心と比べ低下してお り, 予備能も同様に低下しているといわれ, 虚血が 起こりやすい環境にあることは間違いない ${ }^{4)}$. しか し，それだけで恒常的にstrain patternを形成する とは考えにくく，またstrain patternを呈した心筋 がすべて収縮不全を伴っているわけでもない。

では，3番目の心外膜側の活動電位が延長した可 能性はどうか. 健常心では心外膜側と比較して, 心 内膜側では一過性外向き電流 $\left(I_{t o}\right)$ の密度が低く, 不 活性化からの回復が遅い特徵があるため ${ }^{5)}$, 第 1 相 の notchがなく活動電位は長くなる. 一方, $\mathrm{I}_{\mathrm{to}}$ 密度 の高い心外膜側の活動電位にはnotchがあって持続 時間は短くなるためT波は上向きを示す．興味深い ことに，この心外膜側の心筋細胞をアンジオテンシ ン II で培養すると $\mathrm{I}_{\mathrm{to}}$ が減少し, 心内膜側の活動電位 に類似してくるが，反対に心内膜側の細胞を ARB のロサルタンで培養すると第1相の notchが出現し, 心外膜側の活動電位に類似してくることが知られて いる ${ }^{6)}$ ここうしてみると, アンジオテンシン II の増 加は心筋の肥大と線維化によって貫壁性伝導時間を 
伸ばすだけでなく， $I_{t}$ を減少させて心外膜側の活動 電位を延長する作用も加わって stain patternを形成 する，という見方もできる，ロサルタンによる左室 肥大の退縮が $\beta$ 遮断薬よりも顕著であったとする LIFE 試験の結果を重ね合わせれば7)，ARBによる R 波の減高や stain pattern の消失の可能性も現実味を 帯びてくる.

心電図という phenotypeをみながら，心筋の三 次元的構造から細胞の活動電位までを頭に描く. そ の異常から心筋に加わっている圧負荷を感じ，心筋 におけるアンジオテンシンの影響を認識することに よって, 少しでも病気を理解するとともに, 患者の 痛みを共感し，その治療につなげられたら，と願わ ずにはいられない。

\section{〔文献〕}

1 ) Berk BC, Fujiwara K, Lehoux S : ECM remodeling in hypertensive heart disease. J Clin Invest, 2007 ; 117 : $568 \sim 575$

2 ) Peters NS, Green CR, Poole-Wilson PA, Severs NJ : Reduced content of connexin 43 gap junctions in ventricular myocardium from hypertrophied and ischemic human hearts. Circulation, $1993 ; 88: 864 \sim 875$

3 ) Morin DP, Oikarinen L, Viitasalo M, Toivonen L, Nieminen MS, Kjeldsen SE, Dahlöf B, John M, Devereux RB, Okin PM : QRS duration predicts sudden cardiac death in hypertensive patients undergoing intensive medical therapy : the LIFE study. Eur Heart J, 2009 Aug 17 (Epub ahead of print)

4 ) Rembert JC, Kleinman LH, Fedor JM, Wechsler AS, Greenfield JC Jr : Myocardial blood flow distribution in concentric left ventricular hypertrophy. J Clin Invest, $1978 ; 62: 379 \sim 386$

5 ) Näbauer M, Beuckelmann DJ, Uberfuhr P, Steinbeck G : Regional differences in current density and ratedependent properties of the transient outward current in subepicrdial and subendocardial myocytes of human left ventricle. Circulation, $1996 ; 93: 168 \sim 177$

6 ) Yu H, Gao J, Wang H, Wymore R, Steinberg S, McKinnon D, Rosen MR, Cohen IS : Effects of the rennin-angiotensin system on the current Ito in epicardial and endocardial ventricular myocytes from the canine heart. Circ Res, $2000 ; 86: 1062 \sim 1068$

7 ) Devereux RB, Dahlöf B, Gerdts E, Boman K, Nieminen MS, Papademetriou V, Rokkedal J, Harris KE, Edelman JM, Wachtell K : Regression of hypertensive left ventricular hypertrophy by losartan compared with atenolol : the Losartan Intervention for Endpoint Reduction in Hypertension (LIFE) Trial. Circulation, $2004 ; 110: 1456 \sim 1462$ 